\title{
PENAHANAN TERSANGKA TINDAK PIDANA TERORISME DALAM PERSPEKTIF HAK ASASI MANUSIA
}

\author{
Siti Wulandari \\ Master of Law, University of Muhammadiyah Malang, Malang, Indonesia. ndari2406@gmail.com
}

\begin{abstract}
Abstrak: Disahkannya Undang-Undang Nomor 5 Tahun 2018 Tentang Pemberantasan Tindak Pidana Terorisme, menimbulkan pro kontra, salah satunya terkait penambahan masa penahanan di tingkat penyidikan yang awalnya 6 bulan menjadi 9 bulan sebagaimana dalam Pasal 25 ayat (2), (3) dan (4). Hal tersebut sangat berlawanan dengan KUHAP Pasal 24 ayat (1) dan (2) bahwa untuk kepentingan penyidikan dilakukan penahanan selama 20 hari, dan diperpanjang 40 hari. Adanya penambahan masa penahanan di tingkat penyidikan telah menciderai hak hukum dan peradilan tersangka dan juga menciderai asas-asas peradilan pidana yaitu asas persamaan di muka hukum, asas praduga tak bersalah dan asas peradilan cepat, sederhana dan biaya ringan.Tujuan dilakukannya penelitian ini, untuk mengetahui dasar penambahan waktu penahanan di tingkat penyidikan dan untuk mengetahui konsepsi penambahan di tingkat penyidikan yang tidak melanggar hak asasi tersangka. Metode penelitian yang penulis gunakan yaitu pendekatan yuridis normatif, dengan teknik pengumpulan data melalui studi kepustakaan.Undang-Undang Nomor 5 Tahun 2018 disahkan hanya untuk melindungi korban dan kepentingan penyidik saja, tetapi tidak dengan tersangka. Selama 2014-2015 terdapat 554 rangkaian kekerasan dan pelanggaran HAM yang dilakukan oleh Polri dalam melakukan penyidikan. Padahal dalam Keputusan Kapolri No. Pol. Skep/1205/IX/ 2000, Peraturan Kapolri Nomor 8 Tahun 2009, ICCPR, Undang-Undang Hak Asasi Manusia mengatur dengan jelas bahwa tidak boleh melakukan kekerasan dalam proses penyidikan. Tindak pidana terorisme tidak semua termasuk extra ordinary crime, tetapi juga ada yang serious crime. Karena ketika dikatakan sebagai extra ordinary crime ada unsur yang tidak terpenuhi. Saran dengan adanya penelitian ini, pemerintah lebih memperhatikan lagi Undang-Undang Pemberantasan Tindak Pidana Terorisme dan untuk aparat penegak hukum dalam melalukan penyidikan lebih mengutamakan hak asasi manusia. Perlu adanya pedoman khusus untuk aparat penegak hukum terkait tindak pidana terorisme dan monitoring.
\end{abstract}

Kata Kunci: Penahanan; Penyidikan; Tersangka Tindak Pidana Terorisme Hak Asasi Manusia

\section{PENDAhULUAN}

\section{Latar Belakang}

Sejak tahun 1981, Negara Indonesia mengalami berbagai serangan terror dalam skala besar. Oleh karena aksi teror tersebut mengakibatkan ratusan jiwa meninggal dunia dan luka-luka (Wikipedia, 2018). Indonesia pada tahun 2002 terjadi serangan teror di Bali. Dua ledakan besar terjadi di Paddy's Cafe dan Sari Club, korban tewas kurang lebih 200 orang, mayoritas korban yang tewas adalah warga negara asing berasal dari Australia yang sedang berwisata. Serangan teror tersebut tidak bisa diantisipasi oleh pemerintah karena pulau Bali banyak dikunjungi wisatawan Internasional dan memiliki reputasi yang baik sebagai pulau yang aman untuk dikunjungi sebagai tempat wisata (Rahmat, 2017).

Pasca serangan bom bunuh diri yang dilakukan oleh teroris, Polri sebagai institusi penegakan hukum langsung bergerak cepat melakukan penyelidikan dan penyidikan. Pemeriksaan dilakukan secara terstruktur dan sistematis mulai mengamankan tempat kejadian perkara, membantu para korban ledakan bom, memeriksa saksi-saksi yang berada di lokasi saat kejadian dan mengumpulkan barang bukti sisa ledakan yang dianggap memberi petunjuk untuk mengungkap tindak pidana tersebut.

Mendapat serangan teror, pemerintah merespon dengan cepat. Presiden Indonesia langsung mengeluarkan Peraturan Pemerintah Pengganti

56 | Article History, Submitted 11 Feb 2020 - Revision Required 27 Mar 2020 - Accepted 29 Apr 2020. 
Undang-Undang (Perpu) Nomor 1 Tahun 2002 Tentang Pemberantasan Tindak Pidana Terorisme. Perpu tersebut dibentuk karena situasi yang sangat mendesak dalam menanggulangi kejahatan tindak pidana terorisme, karena Kitab Undang-Undang Hukum Pidana Indonesia (KUHP) tidak secara lengkap mengatur tindak pidana terorisme (Rahmat, 2017). Kemudian menjadi Undang-Undang Nomor 5 Tahun 2018 Tentang Perubahan Atas Undang-Undang Nomor 15 Tahun 2003 Tentang Penetapan Peraturan Pemerintah Pengganti Undang-Undang No. 1 Tahun 2002 Tentang Pemberantasan Tindak Pidana Terorisme Menjadi Undang-Undang.

Hamid Awaluddin berpendapat, aksi teror telah menjadi hal yang sangat serius untuk dihadapi. Terorisme, dalam apapun bentuknya dan motif yang melatarbelakangi dipandang sebagai sebuah gerakan yang menghancurkan kehidupan manusia dan martabat karena terorisme membunuh manusia secara masal tanpa memberi kesempatan pada korbannya untuk menyelamatkan diri. Terorisme menjadi kutukan karena aksinya telah membunuh manusia tanpa mengenal batas usia, gender, kondisi kesehatan dan lain sebagainya. Di atas segalanya, aksi teror tidak mengenal perikemanusiaan, teritorial serta batas waktu (Awaluddin, 2012).

Berdasarkan asal usul lahirnya Perpu Nomor 1 Tahun 2002, maka tragedi bom Bali yang terjadi pada 12 Oktober 2002 menjadi fakta sosiologis dan yuridis bagi pemerintah untuk melakukan penegakan hukum terhadap tindak pidana terorisme. Lahirnya Perpu tersebut menjadi Undang-Undang Anti Terorisme telah menimbulkan pro dan kontra di antara berbagai pihak. Adapun beberapa alasan yang dikemukakan oleh kelompok yang kontra terhadap aturan antara lain: 1) Undang-undang tersebut melanggar Hak Asasi Manusia karena diberlakukan surut (retroaktif), yang tidak diketahui pemberlakuannya sampai kapan; 2) Dibuat dalam suasana ketergesaan, sehingga terkesan sekedar menuruti kemauan pihak tertentu, bukan kebutuhan masyarakat; 3) Undang-undang terorisme merupakan wujud "reinkarnasi" dari Undang-Undang No. 11/Pnps/1963 tentang Pemberantasan Kegiatan Subversi. Kekhawatiran tersebut didasarkan pada lamanya waktu penangkapan dan penahanan yang melebihi batas sebagaimana telah ditentukan dalam KUHAP serta adanya kewenangan luar biasa kepada intelijen dalam memberikan laporan (bukti permulaan yang cukup); 4) Aksi teror masih dapat diselesaikan dengan menggunakan hukum pidana umum yaitu KUHP dan KUHAP (Masyhar, 2008).

Terorisme sekarang dipersepsikan sebagai sebuah gerakan HAM yang merupakan hak dasar pada diri manusia, sifatnya universal dan langgeng, oleh karenanya harus dilindungi, dihormati, dipertahankan, tidak boleh diabaikan, dikurangi bahkan dirampas oleh siapapun. Perumusan dan pengakuannya telah diperjuangkan dalam waktu yang panjang. Di era modern ini hal tersebut masih berlangsung, dengan berbagai permasalahan yang muncul karena banyaknya penafsiran yang terkait di dalamnya (Vilano, 2017).

Negara Republik Indonesia merupakan Negara Hukum yang demokratis, berdasarkan Pancasila dan Undang-Undang Dasar NRI 1945. Adapun ciri-ciri Negara Hukum adalah: Pengakuan dan perlindungan atas hak asasi manusia, Pengadilan yang bebas dari pengaruh kekuasaan bahkan kekuatan lain dan tidak memihak, Legalitas dalam segala bentuknya.

Macam-macam Hak Asasi Manusia, diantaranya: Hak Asasi Pribadi, Hak Asasi Ekonomi, Hak Asasi Politik, Hak Asasi Hukum, Hak Asasi Sosial dan Budaya dan Hak Asasi Peradilan. Tetapi dalam penerapannya terdapat problematika hukum, dimana tersangka tindak pidana terorisme tidak terpenuhi hak asasi hukum dan peradilannya. Karena dalam undangundang terbaru yaitu Undang-Undang No. 5 Tahun 2018 Tentang Perubahan Atas Undang-Undang No. 15 Tahun 2003 Tentang Penetapan Peraturan Pemerintah Pengganti Undang-Undang No. 1 Tahun 2002 Tentang Pemberantasan Tindak Pidana Terorisme Menjadi Undang-Undang. Dalam undang-undang tersebut diatur dalam Pasal 25 ayat (2), (3) dan (4) bahwa "Untuk kepentingan penyidikan, penyidik berwenang melakukan penahanan terhadap tersangka dalam waktu paling lama 180 (seratus delapan puluh) hari, diperpanjang 60 hari dan 20 hari".

Pasal tersebut berpotensi tinggi terhadap pengabaian hak-hak tersangka selama proses penyidikan. Penambahan waktu penahanan yang jauh berlebihan dari standar waktu yang diatur dalam Pasal 24 ayat (1) 
dan (2) KUHAP, yaitu: "Masa penahanan dalam Pasal KUHAP pada tahap penyidikan adalah 20 hari dan dapat diperpanjang untuk jangka waktu 40 hari”.

Komisi Nasional Hak Asasi Manusia (Komnas HAM), menyimpulkan bahwa penyebab kematian Siyono, terduga teroris yang ditangkap oleh Densus 88 . Kesimpulan tersebut berdasarkan hasil autopsi yang dilakukan oleh Ikatan Dokter Forensik Indonesia bersama Tim Dokter Forensik Muhammadiyah. Hasil autopsi menyebutkan jenazah mengalami patah pada lima iga bagian kiri, satu iga bagian kanan, tulang dada patah akibat benda tumpul, luka di kepala, serta memar di bagian tubuh belakang. Hasil autopsi berbeda dengan hasil visum yang dilakukan oleh Polisi. Kepala Pusat Kedokteran dan Kesehatan Polri Brigadir Jenderal Arthur Tampi, menyebutkan penyebab kematian Siyono karena kelelahan dan lemas setelah berkelahi dengan anggota Densus 88 . Masyarakat tidak mempunyai kapasitas untuk menguji kebenaran hasil autopsi dan visum, namun masyarakat dapat menyimpulkan adanya kekerasan dalam kasus ini. Polisi juga mengakui ada kesalahan prosedur dalam pengawalan tersangka (Aulianshah, 2016).

Tersangka pencurian SH (35 tahun) diduga, disiksa oleh oknum penyidik Polres Gianyar saat proses introgasi yang dilakukan oleh 8 orang. SH mengalami luka lebam di dada akibat pukulan selang air dan sepatu, bahkan alat kelaminnya ditetesi plastik yang terbakar. Hal tersebut dilakukan, untuk memaksa SH mengaku telah menjambret di 17 TKP, karena tidak kuat SH terpaksa mengiyakan 2 TKP. Bahkan dalam melakukan penangkapan tidak disertai dengan surat perintah penangkapan (Saut, 2017).

Lembaga Bantuan Hukum Jakarta pada 2008 mencatat $83,65 \%$ tersangka mengalami penyiksaan saat diperiksan di wilayah Kepolisian Jakarta. Angka tersebut meningkat dari tahun 2005 yang tercatat $81,1 \%$. Dari data tersebut $77 \%$ penyiksaan dilakukan untuk mendapat pengakuan oleh pelaku dengan bentuk penyiksaan, fisik $57,8 \%$, psikis $71,4 \%$ dan seksual 30\% (Arjawinangun, 2015). Komisi untuk Orang Hilang dan Korban Kekerasan juga mencatat bahwa selama tahun 2014-2015 terdapat 554 kekerasan yang dilakukan oleh Polri. Tindakan yang paling dominan adalah penembakan sewenang-wenang sebanyak 272 peristiwa. Kekerasan tidak hanya terjadi pada tindak pidana terorisme, melainkan juga pada tindak pidana lain (Aulianshah, 2016).

Hal tersebut tidak hanya melanggar hak tersangka dalam suatu peradilan yang cepat dan sederhana dan juga asas praduga tak bersalah. Tetapi juga telah melanggar hak asasi manusia yang telah diamanatkan dalam Undang-Undang Dasar Negara Republik Indonesia (UUD NRI) 1945, diantaranya: hak untuk hidup, hak untuk kemerdekaan dan keamanan secara fisik, serta hak untuk mendapatkan perlakuan yang sama di dalam hukum. Penyiksaan yang dilakukan oleh penyidik tidak hanya berdampak pada luka, melainkan juga berdampak pada kematian. Banyak pihak yang merasa dirugikan, salah satunya adalah keluarga, bahkan ketika pelaku belum ada putusan pengadilan yang menyatakan sah bersalah.

Upaya pemberantasan dalam hal tindak pidana terorisme yang dilakukan pemerintah telah cukup memuaskan. Dalam Naskah Akademik Perubahan Undang-Undang No. 15 Tahun 2003 bahwa penambahan waktu penahanan di tingkat penyidikan yang paling lama dilakukan 6 bulan (4 bulan untuk kepentingan penyidikan dan 2 bulan untuk kepentingan penuntutan). Hal ini masih dirasakan kurang memadai bagi penyidik untuk mengungkap jaringan skala yang luas baik Nasional, Regional maupun Internasional. Karena terorisme yang menurut masyarakat luas tau bahwa dia tergolong dalam extra odinary crime, yang dilakukan secara terorganisir. Sedangkan tindak pidana terorisme yang terjadi di Indonesia sebatas permufakatan jahat, percobaan atau pembantuan untuk melakukan tindak pidana terorisme, dengan penjatuhan pidana dalam putusan hakim sebagian besar di bawah 10 tahun pidana penjara. Penambahan waktu penahanan di tingkat penyidikan lebih tepat diterapkan dalam pendanaan terorisme, karena hal tersebut merupakan faktor utama dalam setiap aksi teror.

Berdasarkan latar belakang di atas, maka penulis mengambil judul penelitian yaitu "Masa Penahanan di Tingkat Penyidikan Terhadap Tersangka Tindak Pidana Terorisme Ditinjau Dari Prinsip-Prinsip Hak Asasi Manusia". 


\section{$\underline{\text { Rumusan Masalah }}$}

Berdasarkan latar belakang tersebut, maka Penulis merumuskan beberapa permasalahan, diantaranya:

1. Apakah yang menjadi pemikiran perbedaan masa penahanan di tingkat penyidikan dalam tindak pidana terorisme?

2. Apakah penambahan masa atau lama penahanan dalam penyidikan tindak pidana terorisme sesuai dengan prinsip-prinsip Hak Asasi Manusia?

3. Bagaimana konsepsi masa penahanan di tingkat penyidikan terhadap tersangka tindak pidana terorisme agar terpenuhi prinsip-prinsip dalam Hak Asasi Manusia bagi tersangka tindak pidana terorisme?

\section{Tujuan}

Berdasarkan rumusan masalah di atas, tujuan penelitian hukum ini adalah sebagai berikut:

1. Untuk mengetahui pemikiran perbedaan masa penahanan di tingkat penyidikan dalam tindak pidana terorisme.

2. Untuk mengetahui penambahan waktu atau lama penahanan dalam penyidikan tindak pidana terorisme sesuai dengan prinsip-prinsip Hak Asasi Manusia

3. Untuk mengetahui konsepsi masa penahanan di tingkat penyidikan terhadap tersangka tindak pidana terorisme agar terpenuhi prinsipprinsip dalam Hak Asasi Manusia bagi tersangka tindak pidana terorisme.

\section{Originalitas Penelitian}

Untuk mengetahui originalitas/keaslian penelitian, untuk itu penulis memaparkan penelitian-penelitian terdahulu yang berkaitan dengan penelitian yang penulis lakukan. Penelitian terdahulu bertujuan sebagai alat pembanding bagi peneliti dalam sebuah penelitian yang akan atau sedang dilakukan, sehingga mengetahui kekurangan maupun kelebihan penelitian tersebut. Selain hal tersebut, dengan adanya penelitian terdahulu dapat terlihat perbedaan substansial yang membedakan antara penelitian yang satu dengan yang lainnya. Diantaranya penelitian terdahulu, adalah sebagai berikut:

\begin{tabular}{|c|c|c|c|c|}
\hline No & Nama dan Judul & Jurnal & $\begin{array}{c}\text { Rumusan } \\
\text { Masalah }\end{array}$ & $\begin{array}{c}\text { Hasil } \\
\text { Penelitian }\end{array}$ \\
\hline 1 & $\begin{array}{l}\text { Tirta Mulya W. P, dan } \\
\text { Khoiril Huda } \\
\text { Penanganan Pelaku } \\
\text { Tindak Pidana } \\
\text { Terorisme (Tipiter) } \\
\text { dalam Perlindungan } \\
\text { HAM }\end{array}$ & $\begin{array}{l}\text { Lex Scientia } \\
\text { Law Review, } \\
\text { Volume } 1 \\
\text { Nomor } 1, \\
\text { November } 2017\end{array}$ & $\begin{array}{l}\text { 1. Bagaimana Hak Asasi } \\
\text { Manusia dalam } \\
\text { penanganan pelaku } \\
\text { tipiter? } \\
\text { 2. Bagaimana proses } \\
\text { penanganan kembali } \\
\text { bagi korban terorisme } \\
\text { di Indonesia? }\end{array}$ & $\begin{array}{l}\text { KUHAP telah merumus } \\
\text { hak bagi tersangka/terda } \\
\text { untuk melindunginya da } \\
\text { berbagai } \\
\text { kemungkinan pelanggar } \\
\text { Hak Asasi Manusia, } \\
\text { sebagaimana diatur dala } \\
\text { Pasal } 50 \text { s/d } 68 \mathrm{KUHAP} \\
\text { Namun dalam penerapal } \\
\text { kepedulian pada } \\
\text { tersangka/terdakwa seriı } \\
\text { tidak dihiraukan oleh ap } \\
\text { penegak hukum. }\end{array}$ \\
\hline
\end{tabular}

\begin{tabular}{|c|c|c|c|c|c|}
\hline 2 & $\begin{array}{l}\text { Danur Vilano } \\
\\
\text { Perlindungan Hak } \\
\text { Tersangka Tindak } \\
\text { Pidana Terorisme } \\
\text { Sebagai Perwujudan } \\
\text { Asas Praduga Tak } \\
\text { Bersalah } \\
\text { (Presumption of } \\
\text { Innocent) } \text { Dalam } \\
\text { Sistem Peradilan } \\
\text { Pidana } \\
\end{array}$ & $\begin{array}{l}e \text { Jurnal } \\
\text { Katalogis, } \\
\text { Volume } 5 \text { No. } \\
\text { 3, Maret } 2017\end{array}$ & & $\begin{array}{l}\text { Bagaimana formulasi } \\
\text { kebijakan dalam } \\
\text { melindungi hak-hak } \\
\text { tersangka tindak pidana } \\
\text { terorisme dalam sistem } \\
\text { peradilan pidana? } \\
\text { Bagaimana formulasi } \\
\text { kebijakan tentang } \\
\text { prosedur penanganan } \\
\text { tersangka tindak pidana } \\
\text { terorisme dalam sistem } \\
\text { peradilan pidana? }\end{array}$ & $\begin{array}{l}\text { Formulasi kebijakan } \\
\text { perlindungan hak tersan } \\
\text { tindak pidana terorisme } \\
\text { secara normatif telah dia } \\
\text { dalam KUHAP dan Perp } \\
1 \text { Tahun } 2002 \text { yang telah } \\
\text { disahkan menjadi Undan } \\
\text { Undang Nomor } 15 \text { Tahu } \\
2003 \text { Tentang Pemberan } \\
\text { Tindak Pidana Terorism }\end{array}$ \\
\hline
\end{tabular}

\begin{tabular}{c|l|l|l|l}
\hline \hline 3 & Sujasmin & Wawasan & Sejauh mana penetapan & Pemberantasan Tipiter \\
& & Yuridika, & aspek hukum pidana & mempunyai sifat berdiri \\
& Penetapan Aspek & Volume 1 & materiel dalam RUU & sendiri, dengan Sistem P \\
& Hukum Pidana & Nomor 1, Maret & Pemberantasan Tipiter? & dan Pemidanaan yang \\
& Materiel Dalam RUU & 2017 & & lainnya, mulai ditetapkaa \\
& Pemberantasan & & sanksi pidana mati, pidal \\
& Tindak Pidana & & penjara seumur hidup, pi \\
& Terorisme & & penjara dan pidana dend \\
& & & dengan ketentuan minim \\
& & & khusus dan maksimum \\
& & & khusus dari pidana penja \\
& & & serta penetapan sanksi pi \\
& bersifat alternatif. \\
\hline
\end{tabular}

\begin{tabular}{|c|c|c|c|c|}
\hline 4 & $\begin{array}{l}\text { Einstein M. Yehosua } \\
\text { Analisa Penanganan } \\
\text { Kasus Tindak Pidana } \\
\text { Terorisme Menurut } \\
\text { UU No. } 15 \text { Tahun } \\
2003\end{array}$ & $\begin{array}{l}\text { Lex Crimen, } \\
\text { Volume } 1 \\
\text { Nomor } 4, \\
\text { Oktober- } \\
\text { Desember } 2012\end{array}$ & $\begin{array}{ll}1 . & \text { Bagaimanakah } \\
\text { kewenangan lembaga- } \\
\text { lembaga Negara yang } \\
\text { khusus menangani } \\
\text { kasus Tindak pidana } \\
\text { terorisme di Indonesia? } \\
\text { 2. } \\
\text { Bagaimanakah } \\
\text { Prosedur Penanganan } \\
\text { kasus Tindak Pidana } \\
\text { Terorisme di Indonesia } \\
?\end{array}$ & $\begin{array}{l}\text { Dalam Prosedur penang: } \\
\text { kasus tindak pidana terol } \\
\text { ini sesuai dengan UU Nc } \\
\text { Tahun } 2003 \text { wajib } \\
\text { dilaksanakan oleh lemba } \\
\text { lembaga Negara yang } \\
\text { diberikan wewenang der } \\
\text { penuh rasa tanggung jaw } \\
\text { dan serius. Baik dari pih } \\
\text { TNI, Kepolisian dan Bac } \\
\text { Intelijen Negara dalam r } \\
\text { proses penyelidikan dan } \\
\text { penangkapan yang sama } \\
\text { mendukung kelancaran } \\
\text { pada proses penyidikan : } \\
\text { akan digelar nanti. }\end{array}$ \\
\hline
\end{tabular}

\section{METODE PENELITIAN}

\section{Metode Pendekatan}

Dalam melakukan peneliian ini menggunakan pendekatan masalah, yaitu proses yang dilakukan untuk mencapai tujuan dari penelitian. Penelitian ini menggunakan metode pendekatan yuridis normatif. Metode tersebut dilakukan dengan cara menelaah hal yang bersifat teoritis mengenai asas, konsep dan norma berkaitan dengan "Masa Penahanan di Tingkat Penyidikan Terhadap Tersangka Tindak Pidana Terorisme Ditinjau Dari Prinsip-Prinsip Hak Asasi Manusia". Pendekatan yuridis normatif disebut juga dengan pendekatan kepustakaan, merupakan penelitian 
yang dilakukan dengan mengkaji jurnal-jurnal, bukubuku, peraturan perundang-undangan dan dokumen lainnya yang ada kaitannya dengan penelitian tersebut. Jenis Bahan Hukum

Dalam melakukan penelitian ini, menggunakan bahan hukum, diantaranya:

a. Bahan Hukum Primer

Bahan hukum primer yang digunakan oleh penulis dalam melakukan penelitian ini, antara lain:

1.Undang-Undang Dasar NRI 1945;

2.Ketetapan Majelis Permusyawaratan Rakyat No. XVII/MPR/1998 Tentang Hak Asasi Manusia;

3.Kitab Undang-Undang Hukum Pidana;

4.Kitab Undang-Undang Hukum Acara Pidana;

5.Undang-Undang Nomor 39 tahun 1999 Tentang Hak Asasi Manusia;

6.Undang-Undang Nomor 15 tahun 2003 Tentang Penetapan Peraturan Pemerintah Pengganti Undang-Undang Nomor 1 Tahun 2002 Tentang Pemberantasan Tindak Pidana Terorisme Menjadi Undang-Undang;

7.Undang-Undang Nomor 5 tahun 2018 Tentang Perubahan Atas Undang-Undang Nomor 15 Tahun 2003 Tentang Penetapan Peraturan Pemerintah Pengganti Undang-Undang Nomor 1 Tahun 2002 Tentang Pemberantasan Tindak Pidana Terorisme Menjadi Undang-Undang;

b. Bahan Hukum Sekunder

Bahan hukum sekunder adalah data yang diperoleh dari melakukan studi kepustakaan, dalam mengkaji jurnal, buku, makalah, draf rancangan peraturan perundang-undangan, Putusan Hakim, Naskah Akademik Undang-Undang Nomor 5 Tahun 2018 Tentang Pemberantasan Tindak Pidana Terorisme atau sumber lainnya yang ada kaitannya dengan penelitian ini serta memberi penjelasan terhadap bahan hukum primer.

\section{Teknik Pengumpulan Bahan Hukum}

Setelah menemukan bahan hukum yang dipakai untuk melakukan penelitian ini, diperlukan teknik pengumpulannya yaitu melalui studi kepustakaan. Dengan cara mengkaji bahan hukum tertulis dari berbagai sumber yang dipublikasikan secara luas, kemudian hasil tersebut dikaji dan disusun secara sistematis.

\section{Teknik Analisis Bahan Hukum}

Teknik analisis bahan hukum dalam penelitian ini, dilakukan setelah ditemukan data-data yang relevan. Analisis dilakukan secara kualitatif, yaitu dengan memilih teori-teori, asas-asas, norma, doktrin dan pasal-pasal yang berkaitan dengan "Masa Penahanan di Tingkat Penyidikan Terhadap Tersangka Tindak Pidana Terorisme Ditinjau Dari Prinsip-Prinsip Hak Asasi Manusia”. Data-data tersebut dianalisis secara kualitatif, yang dituangkan dalam bentuk deskriptif. Sehingga dapat mengungkapkan dan memberikan solusi terhadap masalah yang diteliti.

\section{HASIL PENELITIAN DAN PEMBAHASAN}

\section{Dasar Pemikiran Perbedaan Masa Penahanan di}

Tingkat Penyidikan Dalam Tindak Pidana
$\underline{\text { Terorisme }}$

Naskah Akademik dalam Perubahan UndangUndang Nomor 15 Tahun 2003 Tentang Pemberantasan Tindak Pidana Terorisme, Bab II Kajian Teoritis dan Praktik Empiris dalam kajian terhadap praktik penyelenggaraan, kondisi yang ada, serta permasalahan yang dihadapi oleh masyarakat, poin penangkapan dan penahanan menjelaskan bahwa berdasarkan pengalaman proses penyidikan kasus tindak pidana terorisme tidak bisa dilakukan dengan cara biasa seperti melakukan penyidikan dalam tindak pidana umum, seperti: pencurian, pembunuhan, dan lain-lain. Laporan Intelijen harus dimanfaatkan oleh penyidik untuk dijadikan bukti permulaan dalam melakukan penyidikan.

Dalam Pasal 25 ayat (2) Undang-Undang No. 15 Tahun 2003 "Untuk kepentingan penyidikan dan penuntutan, penyidik diberi wewenang untuk melakukan penahanan terhadap tersangka paling lama 6 (enam) bulan". Pasal 28 "Penyidik dalam melakukan penangkapan terhadap setiap orang yang diduga keras melakukan tindak pidana terorisme berdasarkan bukti permulaan yang cukup sebagaimana dimaksud dalam Pasal 26 ayat (2) untuk paling lama $7 \times 24$ jam". Sebagaimana isi pasal tersebut, dirasa masih kurang dalam mengakomodir bagi penyidik dalam melaksanakan tugasnya mengungkap jaringan 
terorisme, sampai skala yang luas. Berikut beberapa kasus tindak pidana terorisme:

a. Bom Bali I pada tahun 2003 dengan berkas No. Pol. BP/60/IV/2003/Satgas, tertanggal 24 April 2003

Tersangka dalam aksi tersebut adalah Ali Imron yang mendapat hukuman seumur hidup. Tersangka ditangkap di Pulau Tanjung Barukang, Provinsi Kalimantan Timur, yang dimana untuk mencapai pulau tersebut dibutuhkan waktu kurang lebih dua puluh hari untuk dibawa ke Polda Bali yang harus melewati Balikpapan-Samarinda dengan menyusuri Sungai Mahakam, kemudian menggunakan speedboard untuk menuju ke Tanjung Barukang

\section{b. Tersangka kasus teror kerusuhan di Poso Nomor Berkas Perkara No. Pol. BP/01/VII/2008/Densus dan BP/02/VII/2008}

Tersangka kasus tersebut adalah Dr. Agus Purwanto dan Abu Husna yang tertangkap di Malaysia, karena faktor geografis tersebut serta yuridiksi maka proses penangkapan membutuhkan waktu yang tidak sedikit yaitu kurang lebih 10 hari. Begitu pula dalam kasus terorisme yang lain, dimana penahanan di tingkat penyidikan, secara kuantitas tersangka atau pelaku tindak pidana terorisme dilakukan lebih dari satu orang dengan peran yang berbeda tetapi tujuan sama. Terkait kelompok atau jaringan tersebut maka perlu strategi penyidikan yang tepat dikarenakan dalam setiap kasus yang terungkap banyak tersangka yang tidak menutup kemungkinan para tersangka terposisikan sebagai saksi (mahkota). Naskah Akademik dalam Perubahan Undang-Undang No. 15 Tahun 2003, yang menjadi landasan Filosofis, Yuridis dan Sosiologis adalah:

\section{a. Landasan Filosofis}

Dalam membuat naskah akademik, diperlukan landasan filosofis yang artinya pedoman hidup dalam berbangsa dan bernegara, yaitu Pancasila. Nilai-nilai pancasila yang mencerminkan keadilan, ketertiban dan kesejahteraan sangat diinginkan oleh masyarakat Indonesia. Dalam pembukaan terdapat rumusan pancasila, yang terdapat pada alinea keempat. Alinea keempat memuat tujuan Negara dan dasar Negara, yang pada dasarnya mewujudkan cita hukum (rechtsides) yang menguasai hukum dasar Negara baik tertulis maupun tidak tertulis.
Berdasarkan alinea tersebut perlu adanya suatu pengaturan yang adil bagi pelaku dan korban. Demi terwujudnya ketertiban bagi seluruh masyarakat Indonesia, agar terhindar dari terorisme. Karena terorisme dianggap telah meresahkan masyarakat luas, dan aksi terorisme tidak pernah ada habisnya. Untuk itu perlu adanya pengaturan baik tertulis maupun tidak tertulis.

\section{b. Landasan Yuridis}

Pemerintah mengeluarkan Peraturan Pemerintah Pengganti Undang-Undang Nomor 1 Tahun 2002 yang menjadi Undang-Undang Nomor 15 Tahun 2003 tertanggal 4 April 2003 disahkan menjadi UndangUndang Pemberantasan Tindak PidanaTerorisme. Undang-Undang ini disahkan melihat Kitab UndangUndang Hukum Pidana belum mengatur secara khusus serta kurang mengakomodir dalam melakukan pemberantasan tindak pidana terorisme.

Berbicara politik hukum, kejahatan modern yang terjadi di seluruh dunia telah mempengaruhi pemerintah. Hal ini Pemerintah lakukan dengan memberlakukan undang-undang yang bersifat khusus, diantaranya:

a. Undang-Undang Nomor 15 Tahun 2003 Tentang Penetapan Penetapan Perppu Nomor 1 Tahun 2002 Tentang Pemberantasan Terorisme;

b. Undang-Undang Nomor 20 Tahun 2001 Tentang Perubahan atas Undang-Undang Nomor 31 Tahun 1999 Tentang Pemberantasan Tindak Pidana Korupsi;

c. Undang-Undang Nomor 25 Tahun 2003 Tentang Perubahan Undang-Undang Nomor 15 Tahun 2002 Tentang Tindak Pidana Pencucian Uang;

d. Undang-Undang Nomor 7 Tahun 1992 yang telah diubah dengan Undang-Undang Nomor 10 Tahun 1998 Tentang Tindak Pidana Perbankan.

Di samping itu Indonesia sejak tahun 2006 Indonesia telah meratifikasi 6 Konvensi Internasional dari keseluruhan 12 konvensi yang terkait terorisme, antara lain:

a. The 1997 International Convention for the Supprression of Terrorist bombing (Konvensi Internasional Pemberantasan Pengeboman Oleh Teroris, 1997 disahkan menjadi Undang-Undang Nomor 5 Tahun 2006); 
b. The 1999 International Convention for the Suprression of Financing of Terorism (Konvensi Internasional Pemberantasan Pendanaan Terorisme, 1999 disahkan menjadi UndangUndang Nomor 6 Tahun 2006);

c. Convention on Offences and Certain Other Acts Committed on Board Airfcraft 1963 (Konvensi Internasional Tindak Pidana dan PerbuatanPerbuatan tertentu yang Dilakukan di dalam Pesawat Udara);

d. Convention for the Supression of Unlawful Seizure of Aircraft 1970 (Konvensi Tentang Pemberantasan Penguasaan Pesawat Udara secara Melawan Hukum)

e. Convention for thr Suprression of Unlawful Acts Againts the Safety of Civil Aviation 1971 (Konvensi Tentang Pemberantasan TindakanTindakan Melawan Hukum yang Mengancam Keamanan Penerbangan Sipil);

f. Convention on the Physical Protection of Nuclear Material 1979 (Konvensi Perlindungan Fisik Bahan Nuklir).

\section{c. Landasan Sosiologis}

Sepanjang tahun 2000-2009, Indonesia tercatat telah terjadi 22 kali pengeboman dari skala kecil sampai skala besar.. Pada tanggal 17 Juli 2009 telah terjadi peledakan di Hotel JW Marriot dan Hotel Ritz-Carlton di Mega Kuningan pada Jum'at pagi, dengan menewaskan korban 9 orang dan luka-luka 55 orang. Ledakan bom di Kompleks Perguruan Cikini pada tahun 1962 dalam upaya pembunuhan Presiden Ir. Soekarno, yang berlanjut pada Agustus 2001 di Plaza Atrium, Senen, Jakarta yang mengakibatkan enam orang luka-luka. Semua aksi pengeboman sepanjang tahun tersebut telah menjadi isu dalam Negeri.

Pada tahun 2018 terjadi lima pengeboman yang terjadi di beberapa daerah, diantaranya: Kesatu, Teror Bom di Mako Brimob, Depok, Jawa Barat. Kerusuhan terjadi antara pihak Kepolisian di Komplek Brimob dengan narapidana teroris. Dalam kejadian tersebut, enam anggota polisi dijadikan Sandra. Lima diantaranya meninggal. Satu tahanan teroris juga meninggal atas kejadian tersebut. Pasca kejadian tersebut, 145 narapidana teroris dipindahkan dari Mako Brimob ke Nusakambangan, Cilacap, Jawa Tengah.
Kedua, Bom di 3 Gereja Surabaya. Pada Minggu, 13 Mei 2018 telah terjadi pengeboman di 3 Gereja yang pelakunya diketahui merupakan satu keluarga. Bom diledakkan di Gereja Santa Maria Tak Bercela, GKI Diponegoro dan Gereja Pentakosta Jalan Arjuna. Pelaku merupakan anggota dari kelompok JAD itu tewas dalam melakukan aksinya. Dalam aksinya pelaku mengajak 3 anaknya, yang dua tewas. Peristiwa tersebut juga menewaskan warga gereja, Aloysius Bayu, yang dengan berani mengahalangi motor yang digunakan pelaku memasuki wilayah Gereja Santa Maria Tak Bercela.

Ketiga, Bom di Rusunawa Wonocolo, Sidoarjo. Terjadi pada tanggal 13 Mei 2018, bom tersebut meledak karena pelaku tidak sengaja meledakkan bom rakitannya. Pelaku terror bom merupakan satu keluarga yang masih memiliki hubungan dengan keluarga pelaku terror bom 3 Gereja di Surabaya. Dalam insiden ini tiga orang tewas yang merupakan ayah, ibu dan anak sulung mereka. Tiga anak lainnya mengalami luka dan selanjutnya dilakukan pendampingan oleh KPAI bekerja sama dengan PPA Jawa Timur.

Keempat, Bom Polrestabes Surabaya, tanggal 14 Mei 2018. Sehari setelah kejadian ledakan teror bom di 3 Gereja. Teror kembali dilakukan oleh satu keluarga. Sepasang suami istri dan 3 anaknya mendatangi Polrestabes Surabaya dengan menggunakan dua sepeda motor. Saat masih berada di palang gerbang masuk, bom meledak. Empat dari lima pelaku teror tewas di tempat. Empat polisi dan enam warga sipil juga menjadi korban teror tersebut.

Kelima, Penyerangan Terduga Teroris di Mapolda Riau. Tepat sehari sebelum bulan Ramadhan dimulai, Selasa 16 Mei 2018, Polda Riau juga diserang oleh sekawanan orang yang diduga tergabung dalam kelompok terorisme. Kawanan ini terdiri dari lima orang dengan menggunakan mobil Avanza putih. Pada pukul 09.00 mobil diketahui mendesak masuk ke dalam Mapolda Riau dan dihalangi pihak Kepolisian. Empat orang pelaku turun dari mobil dan melakukan penyerangan dengan menggunakan samurai. Seorang pelaku sempat berusaha kabur, sehingga seorang polisi gugur dalam aksi tersebut karena ditabrak pelaku yang kabur. Empat orang pelaku lainnya tewas tertembak 
polisi. Dua wartawan dikabarkan turut terluka (Damanik, 2018).

Pada awal 2019 juga terjadi bom bunuh diri di kawasan Jalan Cenderawasih, Kota Sibolga, Sumatera Utara. Ledakan bersumber dari rumah terduga Husain atau Abu Hamzah alias Upang (32 tahun). Tidak ada korban jiwa dalam peristiwa tersebut. Tetapi istri dan anak pelaku tewas saat melakukan aksinya (Tribun Medan, 2019). Berdasarkan banyaknya kasus tersebut yang di sepanjang tahun, menjadikan aksi terorisme di Indonesia semakin merejalela. Perlu adanya payung hukum untuk mengatasi hal tersebut, agar para pelaku jera dan tidak terjadi lagi aksi terorisme.

Pengaturan yang ada saat ini dianggap kurang untuk mengatasi masalah terorisme yang berkaitan erat dengan "jaringan". Sejak pengeboman yang terjadi di WTC, dilakukan amandemen terhadap undang-undang terorisme atau apapun penyebutannya dalam negara tersebut. Oleh karena itu, diusulkan diperpanjang terhadap masa penangkapan dan penahanan. Sementara, masalah Badan Pembinaan Hukum Nasional Naskah Akademik dalam Perubahan UndangUndang Nomor 15 Tahun 2003 berkaitan dengan lamanya masa penahanan ini dalam mengungkapan jaringan. Jaringan diyakini selalu menjadi pola kerja pelaku tindak pidana terorisme.

Masa penangkapan tujuh hari tidak sesuai dengan kondisi geografis Indonesia yang cukup luas dan geografis negara lain, dimana tindak pidana terorisme termasuk Extra Ordinary Crime (kejahatan luar biasa). Sehingga masa penangkapan pada tindak pidana terorisme diusulkan diperpanjang dari tujuh hari menjadi tiga puluh hari. Hal tersebut juga dirasa kurang memadai dalam hal penahanan yang hanya 180 hari, karena penyidik bekerja secara tergesa-gesa. Sehingga diusulkan perpanjangan menjadi 270 hari, karena tindak pidana terorisme berbentuk jaringan. Butuh waktu untuk mencari bukti berkaitan dengan kelompok.

Undang-undang pemberantasan tindak pidana terorisme dirasa masih kurang melindungi hak-hak dari semua pihak, dalam hal ini korban dan pelaku. Undangundang tersebut hanya untuk kepentingan korban dan penegak hukum saja. Sedangkan salah satu dari ciri peraturan perundang-undangan yang baik adalah isi peraturannya mengikat secara umum, artinya peraturan tersebut tidak hanya tertuju dan mengikat orang atau golongan tertentu.

2. Penambahan Masa atau Lama Penahanan Dalam Penyidikan Tindak Pidana Terorisme Sesuai dengan Prinsip-Prinsip Hak Asasi Manusia atau Tidak

Diberlakukannya Undang-Undang Nomor 5 Tahun 2018 Tentang Pemberantasan Tindak Pidana Terorisme secara otomatis juga sebagai pertanda bahwa penambahan masa penahanan di tingkat penyidikan semula dari 6 bulan menjadi 9 bulan. Hal tersebut dirasa telah melanggar hak asasi hukum dan peradilan tersangka. Dimana seseorang tidak dapat dinyatakan bersalah melakukan tindak pidana sebelum ada putusan hakim. Asas praduga tidak bersalah yang terkandung dalam Pasal 8 ayat (1) Undang-Undang Nomor 48 Tahun 2009 Tentang Kekuasaan Kehakiman. Realisasi penerapan asas praduga tak bersalah terjadi problematik, berkaitan dengan kedudukan yang tidak seimbang antara tersangka/terdakwa dengan aparat penegak hukum, sehingga dikhawatirkan terjadi tindakan sewenangwenang dari aparat penegak hukum.

Penggunaan cara kekerasan dalam proses pemidanaan oleh polisi sebagaimana juga dikemukakan oleh Rahardjo, dalam penelitiannya bahwa polisi masih sering menggunakan kekerasan untuk mendapatkan pengakuan atas keterangan dari tersangka, membuat asas parduga tak bersalah dalam perkara pidana sangat diutamakan dibanding dengan perkara lainnya. Agar hak asasi tersangka terpenuhi dan tidak dilanggar(Butarbutar, 2011).

Sejarah perkembangan politik di Indonesia, menunjukkan bahwa praktek penangkapan dan penahanan yang dilakukan oleh aparat penegak hukum sering berujung kepada penyiksaan, perampasan kehormatan bahkan penghilangan nyawa demi kepentingan politik yang sedang berkuasa. Hak-hak tersangka yang sudah ditentukan dalam undangundang, baru diberikan setelah didapat pengakuan, yang seharusnya diberikan pada awal penyidikan berlangsung. Sebagaimana dikemukakan oleh Soekanto, bahwa penegakan hukum yang baik tidak hanya dilandasi faktor hukum (undang-undang) yang 
baik dan lengkap, melainkan juga dipengaruhi oleh aparat penegak hukum, fasilitas dan budaya hukum masyarakat.

Hal tersebut juga melanggar asas sederhana, cepat dan biaya ringan. Asas tersebut tidak kalah penting dari asas praduga tak bersalah sebagaimana diatur dalam Pasal 4 ayat (2) Undang-Undang Nomor 48 Tahun 2009 Tentang Kekuasaan Kehakiman. Pengadilan membantu pencari keadilan dan berusaha mengatasi segala hambatan dan rintangan untuk dapat tercapainya peradilan yang sederhana, cepat dan biaya ringan. Sederhana adalah pemeriksaan dan penyelesaian perkara dilakukan dengan cara efektif dan efisien. Biaya ringan adalah biaya perkara yang dijangkau oleh masyarakat. Namun, tidak mengesampingkan ketelitian dan kecermatan dalam mencari kebenaran dan keadilan(Diayanti et al., 2018).

Meskipun di dalam peraturan perundang-undangan telah ditetapkan asas sederhana, cepat dan biaya ringan tetapi dalam prakteknya terdapat halangan dan hambatan. Misalnya dalam kasus tindak pidana terorisme, bahwa tersangka mempunyai hak untuk segera diadili dalam proses persidangan. Sedangkan yang kita ketahui, bertambahnya masa penahanan di tingkat penyidikan yang menjadi 9 bulan menghambat tersangka untuk diajukan ke tingkat selanjutnya yaitu penuntutan.

3. Konsepsi Masa Penahanan di Tingkat Penyidikan Penyidikan Terhadap Tersangka Tindak Pidana Terorisme Agar Terpenuhi PrinsipPrinsip dalam Hak Asasi Manusia Bagi Tersangka Tindak Pidana Terorisme

Perpanjangan masa penahanan dari 6 bulan ke 9 bulan dirasa tidak memenuhi hak-hak seorang tersangka. Karena dalam hal ini tersangka berhak untuk segera diproses ke tingkat selanjutnya yaitu penuntutan. Pada dasarnya Kitab Undang-Undang Hukum Pidana belum mengatur secara khusus dan kurang memadai untuk memberantas tindak pidana terorisme. Pemerintah Indonesia perlu untuk membentuk Undang-Undang Pemberantasan Tindak Pidana Terorisme yaitu dengan menyusun Peraturan Pengganti Undang-Undang Nomor 1 Tahun 2002, yang pada 4 April 2003 disahkan menjadi Undang-Undang Nomor 15 Tahun 2003 Tentang Pemberantasan
Tindak Pidana Terorisme. Keberadaan UndangUndang Pemberantasan Tindak Pidana Terorisme di samping Kitab Undang-Undang Hukum Pidana serta Kitab Undang-Undang Hukum Acara Pidana, merupakan hukum pidana khusus. Hukum pidana yang bersifat khusus, dapat tercipta karena(Loqman, 1990):

a. Pengaruh perkembangan zaman, merubah pola pandangan masyarakat. Dimana yang awalnya dianggap bukan sebagai tindak pidana. Karena perubahan pandangan dan norma dalam masyarakat, menjadi sebuah tindak pidana dan diatur dalam peraturan perundang-undangan hukum pidana. Hal tersebut dinamakan proses kriminalisasi terhadap perbuatan tertentu dalam masyarakat.

b. Undang-undang bersifat khusus diperlukan karena peraturan yang ada dianggap kurang atau tidak memadai lagi. Sedangkan untuk melakukan perubahan undang-undang yang telah ada, memerlukan waktu yang cukup lama.

Hukum Pidana Khusus, bukan hanya mengatur pidana materiilnya saja, akan tetapi juga mengatur hukum acaranya, oleh karena itu harus diperhatikan bahwa aturan tersebut tetap memperhatikan asas-asas umum yang terdapat baik dalam ketentuan umum KUHP bagi hukum pidana materiilnya sedangkan untuk hukum pidana formilnya harus tunduk terhadap ketentuan KUHAP.

Dengan diberlakukannya Undang-Undang Nomor 5 tahun 2018 Tentang Perubahan Atas Undang-Undang Nomor 15 Tahun 2003 Tentang Penetapan Peraturan Pemerintah Pengganti Undang-Undang Nomor 1 Tahun 2002 Tentang Pemberantasan Tindak Pidana Terorisme Menjadi Undang-Undang tidak boleh bertentangan dengan asas-asas yang ada dalam KUHP maupun KUHAP, serta tidak boleh melanggar sistem peradilan pidana dan hak asasi manusia. Tetapi nyatanya yang terjadi Undang-Undang nomor 5 Tahun 2018 banyak pasal di dalamnya, yang masih tidak memenuhi hak-hak seorang tersangka.

Dalam Pasal 25 ayat (2), (3) dan (4) bahwa "Untuk kepentingan penyidikan, penyidik berwenang melakukan penahanan terhadap tersangka dalam waktu paling lama 180 (seratus delapan puluh) hari, diperpanjang 60 hari dan 20 hari". Hal ini melanggar 
hak seorang tersangka yaitu peradilan yang bebas, cepat dan sederhana. Artinya tersangka mempunyai hak untuk segera diproses ke tingkat selanjutnya, yaitu penuntutan karena selama belum ada putusan pengadilan, maka seseorang belum bisa dikatakan secara sah melakukan sebuah tindak pidana (asas praduga tak bersalah).

Putusan No. 222/Pid.B/2006/PN.AB, tertanggal 15 Maret 2006 dengan terdakwa Rusli Amiludin alias Rusli, yang didakwa: Dakwaan Kesatu, Pasal 15 Jo Pasal 6; Dakwaan kedua Pasal 13 huruf c UndangUndang Nomor 15 Tahun 2003. Tuntutan dari Penuntut Umum yaitu menyatakan terdakwa terbukti secara bersalah melakukan perbuatan yang dengan sengaja memberi bantuan atau kemudahan terhadap pelaku tindak pidana terorisme, dengan menyembunyikan informasi, dan menjatuhkan pidana penjara 7 tahun. Hakim menjatuhkan putusan, bahwa terdakwa terbukti bersalah melanggar Pasal 13 huruf $\mathrm{c}$ dan dijatuhi pidana penjara 7 tahun.

Putusan No. 878/Pid.Sus/2011/PN.Jkt.Bar, tertanggal 4 Agustus 2011 dengan terdakwa Taufik bin Marzuki alias Abu Sayaf alias Alex Nurdin Sulaiman bin Tarmizi yang didakwa, dakwaan kesatu: Pasal 9 jo Pasal 15 dan dakwaan kedua: Pasal 13 huruf c UndangUndang Nomor 15 Tahun 2003. Tuntutan dari Penuntut Umum yaitu terdakwa terbukti secara sah melakukan tindak pidana yang diatur dalam Pasal 15 jo Pasal 9 dan pidana penjara 8 tahun. Pengadilan Negeri Jakarta Barat menjatuhkan putusan, terdakwa terbukti secara sah melakukan tindak pidana terorisme dan pidana penjara 5 tahun 6 bulan.

Tindak pidana terorisme yang diatur dalam UndangUndang Nomor 5 Tahun 2018 tidak semuanya termasuk Extra Ordinary Crime, melainkan Serious Crime. Karena yang termasuk dalam Extra Ordinary Crime, diantaranya: kejahatan genosida, kejahatan terhadap kemanusiaan, kejahatan perang, kejahatan agresi. Berdasarkan Statuta Roma Mahkamah Pidana Internasional, yang disahkan oleh Konferensi Diplomatik Perserikatan Bangsa-Bangsa pada tanggal 17 Juli 1998, mengatur kualifikasi Extra Ordinary Crime, diantaranya:

\section{a. Pasal 6 Genosida}

Genosida artinya setiap perbuatan berikut ini yang dilakukan dengan tujuan untuk menghancurkan, seluruhnya atau untuk sebagian, suatu kelompok nasional, etnis, ras atau keagamaan, seperti diantaranya:

1) Membunuh anggota kelompok tersebut;

2) Menimbulkan luka fisik atau mental yang serius terhadap para anggota kelompok tersebut;

3) Secara sengaja menimbulkan kondisi kehidupan atas kelompok tersebut yang diperhitungkan akan menyebabkan kehancuran fisik secara keseluruhan atau untuk sebagian;

4) Memaksakan tindakan-tindakan yang dimaksud untuk mencegah kelahiran dalam kelompok tersebut;

5) Memindahkan secara paksa anak-anak dari kelompok itu kepada kelompok lain.

\section{b. Pasal 7 Kejahatan terhadap Kemanusiaan}

Kejahatan terhadap kemanusiaan, berarti salah satu dari perbuatan berikut ini apabila dilakukan sebagai bagian dari serangan meluas atau sistematik yang ditujukan kepada suatu kelompok penduduk sipil, dengan mengetahui adanya serangan itu:

1) Pembunuhan

2) Pemusnahan

3) Perbudakan

4) Deportasi

5) Penyiksaan

6) Perkosaan, perbudakan seksual, pemaksaan prostitusi, penghamilan paksa, pemaksaan sterilisasi, atau suatu bentuk kekerasan seksual lain yang cukup berat.

7) Penganiayaan terhadap suatu kelompok yang dapat diidentifikasi atau kolektivitas atas dasar politik, ras, nasional, etnis, budaya, agama, gender

8) Penghilangan paksa

9) Kejahatan apartheid

10) Perbuatan tak manusiawi lain dengan sifat sama yang secara sengaja menyebabkan penderitaan berat, atau luka serius terhadap badan atau mental atau kesehatan fisik.

c. Pasal 8 Kejahatan Perang

Yang termasuk kejahatan perang, diantaranya: 
1) Pelanggaran berat terhadap Konvensi Jenewa tertanggal 12 Agustus 1949, yaitu masing-masing dari perbuatan berikut ini terhadap orang-orang atau hak-milik yang dilindungi.

2) Pelanggaran serius lain terhadap hukum dan kebiasaan yang dapat diterapkan dalam sengketa bersenjata internasional, dalam rangka hukum internasional yang ditetapkan, yaitu salah satu perbuatan-perbuatan berikut ini:

a) Secara sengaja melancarkan serangan terhadap sekelompok penduduk sipil atau terhadap setiap orang sipil yang tidak ikut serta secara langsung dalam pertikaian itu;

b) Secara sengaja melakukan serangan terhadap objek-objek sipil, yaitu, objek yang bukan merupakan sasaran militer;

c) Menyerang atau membom, dengan sarana apa pun, kota-kota, desa, perumahan atau gedung yang tidak dipertahankan atau bukan objek militer;

d) Membunuh atau melukai seorang lawan yang, setelah meletakkan senjata atau tidak mempunyai sarana pertahanan lagi, telah menyerahkan diri atas kemauannya sendiri;

e) Memanfaatkan secara tidak benar bendera gencatan senjata, atau bendera atau lencana dan seragam militer dari pihak lawan atau milik Perserikatan Bangsa-Bangsa, maupun tanda-tanda khusus dari Konvensi Jenewa, yang menyebabkan kematian atau luka-luka serius pada individu-individu tertentu, dan lain-lain.

Sedangkan tindak pidana terorisme yang terjadi di Indonesia, mayoritas berupa penyertaan (deelneming). Penyertaan adalah perbuatan tindak pidana yang dilakukan oleh lebih dari satu orang yang saling terkait dan secara sadar mengetahui apa yang dilakukan, tetapi juga ada yang dikarenakan unsur paksaan. Penyertaan diatur dalam Pasal 55 dan 56 KUHP yang berarti ada dua orang atau lebih mengambil bagian untuk mewujudkan suatu tindak pidana dapat disebutkan bahwa seseorang tersebut turut serta dalam hubungannya dengan orang lain(Effendi, 2011).

Prof. Satochid Kartanegara mengartikan Deelneming apabila dalam satu delik tersangkut beberapa orang atau lebih dari satu orang. Menurut doktrin, Deelneming menurut sifatnya terdiri atas (Kartanegara, 1998):

a. Deelneming yang berdiri sendiri, yakni pertanggung jawaban dari setiap peserta dihargai sendiri-sendiri.

b. Deelneming yang tidak berdiri sendiri, yakni pertanggung jawaban dari peserta yang satu digantungkan dari perbuatan peserta yang lain.

Sedangkan klasifikasi penyertaan menurut Pasal 55 dan 56 KUHP, antara lain:

a. Pembuat (dader), yang terdiri dari: Pasal 55

1) Melakukan (plegen)

2) Menyuruh melakukan (doen plegen)(Hiariej, 2014)

3) Turut serta melakukan (medeplegen)

4) Menganjurkan melakukan (uitlokken)

b. Pembantu kejahatan (medeplichtige) Pasal 56

Tentang pertanggungjawaban pembantuan diatur dalam Pasal 57 KUHP:

(1) Dalam hal pembantuan, maksimum pidana pokok terhadap kejahatan dikurangi sepertiga;

(2) Jika kejahatan diancam dengan pidana mati atau pidana penjara seumur hidup, dijatuhkan pidana penjara paling lama lima belas tahun;

(3) Pidana tambahan bagi pembantuan sama dengan kejahatannya sendiri;

(4) Dalam menentukan pidana bagi pembantu, yang diperhitungkan hanya perbuatan yang sengaja dipermudah atau diperlancar olehnya, beserta akibat-akibatnya.

Oleh sebab itu, tidak semua kejahatan yang masuk dalam Undang-Undang Pemberantasan Tindak Pidana Terorisme termasuk extra ordinary crime, melainkan serious crime, maka dari itu penulis mengklasifikasikan sebagai berikut:

\begin{tabular}{|l|l|l|}
\hline No & Pengaturan & Keterangan \\
\hline 1 & Pasal 6 & \\
& Setiap orang yang & \\
& dengan sengaja & Extra \\
& menggunakan & Ordinary \\
& kekerasan atau & Crime \\
& ancaman yang & \\
& menimbulkan suasana & \\
& teror atau rasa takut & \\
\hline
\end{tabular}




\begin{tabular}{|c|c|c|}
\hline & $\begin{array}{l}\text { terhadap seseorang } \\
\text { secara meluas, } \\
\text { menimbulkan korban } \\
\text { bersifat masal dengan } \\
\text { cara merampas } \\
\text { kemerdekaan atau } \\
\text { menghilangkan nyawa } \\
\text { serta harta benda } \\
\text { orang lain atau } \\
\text { mengakibatkan } \\
\text { kerusakan/kehancuran } \\
\text { terhadap objek vital } \\
\text { yang strategis, } \\
\text { lingkungan hidup atau } \\
\text { fasilitas publik atau } \\
\text { internasional. }\end{array}$ & \\
\hline 2 & Pasal 7 & $\begin{array}{l}\text { Extra } \\
\text { Ordinary } \\
\text { Crime }\end{array}$ \\
\hline 3 & $\begin{array}{l}\text { Pasal } 8 \\
\text { Perbuatan } \\
\text { menghancurkan atau } \\
\text { merusak bangunan } \\
\text { yang digunakan untuk } \\
\text { kemananan lalu lintas } \\
\text { udara, termasuk } \\
\text { merusak pesawat } \\
\text { udara. }\end{array}$ & $\begin{array}{l}\text { Extra } \\
\text { Ordinary } \\
\text { Crime }\end{array}$ \\
\hline 4 & $\begin{array}{l}\text { Pasal } 9 \\
\text { Perbuatan melawan } \\
\text { hukum membawa } \\
\text { masuk ke Indonesia, } \\
\text { membuat, menerima, } \\
\text { mencoba memperoleh, } \\
\text { menyerahkan dan/atau } \\
\text { mencoba } \\
\text { menyerahkan, } \\
\text { menguasai, dst senjata } \\
\text { api, amunisi atau } \\
\text { bahan peledak dan } \\
\text { bahan-bahan lainnya } \\
\text { yang berbahaya. }\end{array}$ & Serious Crime \\
\hline 5 & Pasal $10 \mathrm{~A}$ & Serious Crime \\
\hline
\end{tabular}

\begin{tabular}{|c|c|c|}
\hline & $\begin{array}{l}\text { Perbuatan melawan } \\
\text { hukum membawa } \\
\text { masuk ke Indonesia, } \\
\text { membuat, menerima, } \\
\text { mencoba memperoleh, } \\
\text { menyerahkan dan/atau } \\
\text { mencoba } \\
\text { menyerahkan, } \\
\text { menguasai, dst senjata } \\
\text { kimia, senjata biologi, } \\
\text { radiologi, } \\
\text { mikroorganisme, } \\
\text { nuklir, radioaktif atau } \\
\text { komponennya } \\
\text { juga dan } \\
\text { memperdagangkan }\end{array}$ & \\
\hline 6 & $\begin{array}{l}\text { Pasal 11 } \\
\text { Pendanaan untuk } \\
\text { melakukan tindak } \\
\text { pidana terorisme }\end{array}$ & $\begin{array}{l}\text { Extra } \\
\text { Ordinary } \\
\text { Crime }\end{array}$ \\
\hline 7 & $\begin{array}{l}\text { Pasal 12 A } \\
\text { Setiap orang yang } \\
\text { merencanakan, } \\
\text { menggerakkan atau } \\
\text { mengorganisasikan } \\
\text { tindak pidana } \\
\text { terorisme di dalam } \\
\text { maupun luar negeri } \\
\text { Pasal 12 A } \\
\text { Setiap orang dengan } \\
\text { sengaja } \\
\text { menyelenggarakan, } \\
\text { memberikan dan/atau } \\
\text { mengikuti pelatihan } \\
\text { militer, dsb dengan } \\
\text { maksud } \\
\text { merencanakan, } \\
\text { mempersiapkan } \\
\text { dan/atau melakukan } \\
\text { tindak pidana } \\
\text { terorisme }\end{array}$ & $\begin{array}{l}\text { Extra } \\
\text { Ordinary } \\
\text { Crime }\end{array}$ \\
\hline 8 & $\begin{array}{l}\text { Pasal 13 A } \\
\text { Setiap orang yang } \\
\text { memiliki hubungan }\end{array}$ & Serious Crime \\
\hline
\end{tabular}




\begin{tabular}{|c|c|c|}
\hline & $\begin{array}{lr}\text { dengan } & \text { organisasi } \\
\text { terorisme dan dengan } \\
\text { sengaja menyebarkan } \\
\text { ucapan, sikap atau } \\
\text { perilaku, tulisan atau } \\
\text { tampilan } \\
\text { tujuan dengan } \\
\text { orang atau kelompok } \\
\text { untuk melakukan } \\
\text { kekerasan }\end{array}$ & \\
\hline 9 & $\begin{array}{l}\text { Pasal 14 } \\
\text { Setiap orang yang } \\
\text { dengan sengaja } \\
\text { menggerakkan orang } \\
\text { lain untuk melakukan } \\
\text { tindak pidana } \\
\text { terorisme. }\end{array}$ & $\begin{array}{l}\text { Extra } \\
\text { Ordinary } \\
\text { Crime }\end{array}$ \\
\hline 10 & $\begin{array}{l}\text { Pasal 15 } \\
\text { Setiap orang yang } \\
\text { melakukan } \\
\text { permufakatan jahat, } \\
\text { persiapan, percobaan } \\
\text { atau pembantuan } \\
\text { untuk melakukan } \\
\text { tindak pidana } \\
\text { terorisme }\end{array}$ & Serious Crime \\
\hline 11 & $\begin{array}{lr}\text { Pasal 16 A } & \\
\text { Setiap orang yang } \\
\text { melakukan } & \text { tindak } \\
\text { pidana } & \text { terorisme } \\
\text { dengan } & \text { melibatkan } \\
\text { anak } & \end{array}$ & $\begin{array}{l}\text { Extra } \\
\text { Ordinary } \\
\text { Crime }\end{array}$ \\
\hline 12 & \begin{tabular}{lr} 
Pasal 17 & \\
Korporasi yang \\
melakukan tindak \\
\multicolumn{2}{l}{ pidana terorisme }
\end{tabular} & $\begin{array}{l}\text { Extra } \\
\text { Ordinary } \\
\text { Crime }\end{array}$ \\
\hline
\end{tabular}

\section{Tabel 1. Pasal Tindak Pidana Terorisme}

Penangkapan dan penahanan merupakan dari tindakan upaya paksa dimana pelaksanaannya dapat melanggar kebebasan bergerak sehingga diperlukan pengaturan untuk menghindari terjadinya penangkapan dan penahanan sewenang-wenang. Pasal 9 International Convenant on Civil and Political Rights (ICCPR). Untuk masa penahanan di tingkat penyidikan dalam perubahan Undang-Undang Pemberantasan
Tindak Pidana Terorisme Nomor 5 Tahun 2018 lebih tepat diterapkan dalam Pasal 6, 7, 8, 11, 12, 14, 16 A dan 17. Sedangkan untuk tindak pidana terorisme yang merupakan penyertaan dalam hal pembantuan sebagaimana diatur dalam Pasal 9, 10 A, 13 A dan 15 perlu dirumuskan lagi.

\section{Kesimpulan}

\section{PENUTUP}

Berdasarkan hasil pembahasan di atas, maka penulis mengambil kesimpulan, sebagai berikut:

a. Bahwa penambahan masa penahanan di tingkat penyidikan, dilandasi dengan landasan filosofis, yuridis dan sosiologis. Dalam landasan filosofis, untuk mencapai cita hukum, maka perlu adanya pengaturan baik secara tertulis maupun tidak tertulis. Landasan yuridis mengatakan, bahwa terdapat 6 Konvensi Internasional untuk mengakomodir tindak pidana terorisme. Selanjutnya landasan sosiologis, bahwa aksi terorisme sampai tahun 2019 selalu terjadi, dan hal tersebut telah meresahkan masyarakat. Bahwa dalam pembuatan peraturan perundang-undangan harus berdasarkan asas proporsionalitas, dimana peraturan menghendaki kepentingan masyarakat, negara, pelaku dan korban tindak pidana. Tetapi tidak dengan Undang-Undang Nomor 5 Tahun 2018 yang hanya menghendaki kepentingan korban dan aparat penegak hukum saja.

b. Penambahan masa penahanan di tingkat penyidikan telah melanggar hak-hak seseorang sebagai tersangka. Dimana sesuai dengan Pasal Pasal 8 ayat (1) Undang-Undang Nomor Kekuasaan Kehakiman, seseorang tidak boleh dinyatakan bersalah melakukan tindak pidana, sebelum ada putusan hakim. Hal tersebut juga melanggar Pasal 4 ayat (2), yaitu asas peradilan cepat, sederhana dan biaya ringan. Dalam hal ini tersangka hak untuk segera diajukan ke tingkat selanjutnya (penuntutan) tidak terpenuhi. Selama 2014-2015 terdapat 554 rangkaian kekerasan dan pelanggaran HAM yang dilakukan oleh Polri dalam melakukan penyidikan. Padahal dalam Keputusan Kapolri No. Pol. Skep/1205/IX/ 2000, Peraturan Kapolri Nomor 8 Tahun 2009, ICCPR, Undang-Undang Hak Asasi Manusia mengatur 
dengan jelas bahwa tidak boleh melakukan kekerasan dalam proses penyidikan.

c. Extra Ordinary Crime diantaranya: kejahatan genosida, kejahatan terhadap kemanusiaan, kejahatan perang, kejahatan agresi. Dalam kejahatan terhadap kemanusiaan serangannya meluas dan sistematik. Oleh sebab itu tidak semua tindak pidana dalam Undang-Undang Nomor 5 Tahun 2018 sebagai Extra Ordinary Crimes. Tindak pidana terorisme yang terjadi di Indonesia mayoritas di dominasi dengan tindak pidana pembantuan, yang ancaman pidananya di bawah 10 tahun.

\section{$\underline{\text { Saran }}$}

Berdasarkan hasil pembahasan di atas dengan adanya penelitian hukum ini, Penulis berharap:

a. Untuk Pemerintah, bahwa tindak pidana terorisme masih belum secara massif ditanggulangi dengan Undang-Undang Nomor 5 Tahun 2018. Untuk itu perlu dilakukan Judicial Review terhadap UndangUndang Nomor 5 Tahun 2018 Tentang Pemberantasan Tindak Pidana Terorisme, terutama dalam masa penahanan di tingkat penyidikan. Karena pelaku merasa haknya dilanggar, sehingga hal tersebut membut pelaku merasa tidak jera.

b. Perlu dibuatkan pedoman untuk Kepolisian, Penasehat Hukum, Penuntut Umum dan Hakim terkait kualifikasi tindak pidana terorisme yang termasuk Extra Ordinary Crime dan Serious Crime. Sehingga dapat diketahui dalam penerapan masa penahanan di tingkat penyidikan, agar hakhak sebagai tersangka terpenuhi.

c. Untuk Kepolisian karena tindak pidana terorisme merupakan tindak pidana yang sangat meresahkan masyarakat. Untuk itu dalam melakukan penyidikan harus menjunjung tinggi hak-hak asasi manusia.

d. Perlu adanya monitoring dari suatu lembaga mengenai penyidikan terhadap tersangka tindak pidana terorisme. Sehingga nanti ada evaluasi, yang dapat dijadikan untuk kebaikan kedepannya dalam menanggulangi tindak pidana terorisme.

e. Untuk masyarakat, agar menjaga dirinya untuk tidak mengikuti ajaran-ajaran yang bersifat radikalisme. Begitu juga dalam mengikuti pelatihan-pelatihan militer yang belum jelas asal usulnya.

\section{REFERENSI}

Anwar, Y., \& Adang. (2009). Sistem Peradilan Pidana: Konsep, Komponen dan Pelaksanaannya dalam Penegakan Hukum di Indonesia. Widya Padjajaran.

Arjawinangun, K. B. (2015). Kasus Kekerasan Terhadap Tersangka Saat Diperiksa Meningkat. Sindonews.Com. https://metro.sindonews.com/berita/1019092/170 /kasus-kekerasan-terhadap-tersangka-saatdiperiksa-meningkat

Atmasasmita, R. (1996). Sistem Peradilan Pidana Perspektif Eksistensialisme dan Abolisionisme. Putra Abardin.

Aulianshah, K. (2016). Polisi Harus Hentikan Kekerasan Dalam Penyidikan. Beritagar.Id. https://beritagar.id/artikel/editorial/polisi-harushentikan-kekerasan-dalam-penyidikan

Awaluddin, H. (2012). HAM Politik, Hukum, \& Kemunafikan Internasional. Kompas Media Nusantara.

Berutu, E. S. (2017). Penangkapan dan Penahanan Tersangka Menurut KUHAP Dalam Hubungannya Dengan Hak Asasi Manusia. Lex Crimen, VI(6), 86-87.

Butarbutar, E. N. (2011). Asas Praduga Tidak Bersalah Penerapan dan Pengaturannya Dalam Hukum Acara Perdata. Jurnal Dinamika Hukum, 11(3), 472-473.

Damanik, M. J. (2018). 5 Kasus Teror di Indonesia Selama Mei 2018. IDN TIMES.

https://www.idntimes.com/news/indonesia/margi th-juita-damanik/5-kasus-teror-di-indonesiaselama-mei

Diayanti, Y. U., Ilham, L., \& Haris, H. (2018). Implementasi Asas Sederhana Cepat dan Biaya Ringan Dalam Perkara Perceraian di Pengadilan Agama Kelas IIB Mamaju Sulawesi Barat. Jurnal Tomalebbi, V(2), 163. 
Effendi, E. (2011). Hukum Pidana Indonesia. Refika Aditama.

Hiariej, E. O. S. (2014). Prinsip-Prinsip Hukum Pidana. Cahaya Atma Pustaka.

K.M, R., \& Smith. (2008). Hukum Hak Asasi Manusia. PUSHAM UII.

Kader, A. S. (2014). Pemeriksaan Tersangka Oleh Penyidik Berdasarkan Kitab Undang-Undang Hukum Acara Pidana. Jurnal Ilmu Hukum Legal Opinion, 2(2), 2.

Kartanegara, S. (1998). Hukum Pidana Kumpulan Kuliah. Balai Lektur Mahasiswa.

Loqman, L. (1990). Analisis Hukum dan PerundangUndangan Kejahatan terhadap Keamanan Negara di Indonesia. Universitas Indonesia.

Masriani, Y. T. (2004). Pengantar Hukum Indonesia. Sinar Grafika.

Masyhar, A. (2008). Gaya Indonesia Menghadang Terorisme Sebuah Kritik Atas Kebijakan Hukum Pidana Terhadap Tindak Pidana Terorisme di Indonesia. Mandar Maju.

Nasution, A. R. (2017). Terorisme Sebagai "Extraordinary Crime" Dalam Perspektif Hukum dan Hak Asasi Manusia. Jurnal Hukum Responsif FH UNPAB, 5(5), 94.

Rahmat, M. (2017). Politik Hukum Terhadap Tindak Pidana Terorisme Dalam Pembaharuan Hukum Pidana Indonesia. Jurnal Wawasan Yuridika, 1(2), 157.

Saut, P. D. (2017). Oknum Polisi di Bali Diduga Siksa Alat Vital Tersangka Pencurian. Detiknews. https://news.detik.com/berita/d-3600955/oknumpolisi-di-bali-diduga-siksa-alat-vital-tersangkapencurian

Sefriani. (2013). Karakteristik The Most Serious Crime Menurut Hukum Internasional Dalam Putusan Mahkamah Konstitusi (Kajian Putusan Mahkamah Konstitusi Nomor 15/PUU-X/2012). Jurnal Yudisial, 6(2), 100.

Tribun Medan. (2019). Kesaksian Warga Bom Bunuh Diri Ibu dan Bayi 2 Tahun Suaranya Kuat Kali, Ini Kronologi Teror Sibolga. Wartakotalive.Com. https://wartakota.tribunnews.com/2019/03/14/ke saksian-warga-bom-bunuh-diri-ibu-dan-bayi-2tahun-suaranya-kuat-kali-ini-kronologi-terorsibolga

Vilano, D. (2017). Perlindungan Hak-Hak Tersangka Terorisme Sebagai Perwujudan Asas Praduga Tak Bersalah Dalam Sistem Peradilan Pidana. Jurnal Katalogis, 5(3), 183.

Wahid, A., Sunardi, \& Sidik, M. I. (2004). Kejahatan Terorisme Perspektif Agama, HAM dan Hukum. PT Refika Aditama.

Wikipedia. (2018). Terorisme di Indonesia. Wikipedia. https://id.wikipedia.org/wiki/Terorisme_di_Indo nesia 